\title{
What do we need to know about anatomy in gynaecology? An international validation study
}

\author{
Dorothea Koppes ${ }^{1}$, Anniko Snoeren², Roy Kruitwagen ${ }^{3}$, Fedde Scheele ${ }^{4}$, Annelieke \\ Schepens-Franke ${ }^{5}$, and Kim Notten ${ }^{5}$ \\ ${ }^{1}$ Maastricht UMC+ \\ ${ }^{2}$ Maastricht University \\ ${ }^{3}$ GROW, School for Oncology and Developmental Biology, Maastricht University Medical \\ Centre \\ ${ }^{4}$ Vrije Universiteit Amsterdam \\ ${ }^{5}$ Radboudumc
}

March 2, 2022

\begin{abstract}
Objective: international validation of the Dutch Delphi consensus study about which anatomical structures that should be taught to ensure safe and competent practice among general gynaecologists. Design: Validation study. Setting: Academic, non-academic teaching and non-academic, non-teaching hospitals worldwide. Population: Gynaecologists and trainees in gynaecology. Methods: The relevance of 123 items included in the Dutch Delphi study was scored on a Likert scale between 1 (not relevant) and 5 (highly relevant). Consensus was defined when ? $70 \%$ of the panellist scored the item as relevant or very relevant and the average rating was ? 4. Main Outcome Measures: Clinically relevant anatomical structures. Results: A total of 192 gynaecologists and trainees from seven countries (Belgium, Germany, Norway, Oceania, Sweden, United Kingdom and United States) completed the questionnaire. Of the 123 structures, 72 (58.5\%) were internationally relevant. When the 72 relevant structures from the international Delphi study were compared with the 86 relevant structures from the Dutch Delphi study, $70(81.4 \%)$ structures matched. Conclusions: This study identified 70 anatomical structures that should be taught for safe and competent practice of general gynaecologists based on national and international validation. The results of our study identify the learning needs (i.e., the content) for an international anatomy curriculum. The development of the curriculum (i.e., the form) can be determined by each country and used to standardize and guide postgraduate training in gynaecology. This is an important step in the era of international teaching and training.
\end{abstract}

\section{Hosted file}

Manuscript.docx available at https://authorea.com/users/463160/articles/558340-what-do-weneed-to-know-about-anatomy-in-gynaecology-an-international-validation-study

\section{Hosted file}

Table 1 Baseline characteristics .docx available at https://authorea.com/users/463160/ articles/558340-what-do-we-need-to-know-about-anatomy-in-gynaecology-an-internationalvalidation-study

\section{Hosted file}

Table 2 Percentage_mean_SD.docx available at https://authorea.com/users/463160/articles/ 558340-what-do-we-need-to-know-about-anatomy-in-gynaecology-an-international-validation- 
study

\section{Hosted file}

Figure 1 International Delphi.docx available at https://authorea.com/users/463160/articles/ 558340-what-do-we-need-to-know-about-anatomy-in-gynaecology-an-international-validationstudy

\section{Hosted file}

Figure 2 Development of a curriculum.docx available at https://authorea.com/users/463160/ articles/558340-what-do-we-need-to-know-about-anatomy-in-gynaecology-an-internationalvalidation-study 